\title{
Chinese Discourse on Human Rights in Global Governance
}

\author{
Pinghua Sun ${ }^{1}$ \\ China University of Political Science and Law, Beijing, China \\ fadaphsun@aliyun.com
}

\begin{abstract}
China's discourse on human rights has a very rich and colorful content and the construction thereof has its own particular characteristics. Approaches to examine it should be adopted to understand thoroughly both the past and the present and both Chinese and Western methods of integration of theory into practice. Many important human rights factors are embodied in traditional Chinese culture and Confucianism became an important basis of the international consensus on morality. The Chinese representative, Peng-chun Chang made historical contributions to the construction of the international human rights protection system. These represent the core texts in constructing China's human rights discourse, which will play an important role in China's struggle for authority in the international discourse on human rights and dominance in global governance.
\end{abstract}

* This article is the author's phased achievement for China Academic Translation Project of the National Social Science Fund- "Historic Achievement of a Common Standard: Pengchun Chang and the Universal Declaration of Human Rights" (its number of approval: 14WFX005); and it is also the phased achievement for the key research project of the Chinese Law Association-On the Improvement of the Human Rights Judicial Guarantee System, the project number: CLS (2014)Bo7. At the same time, it is also sponsored by "Humanities and Social Science Research Project of China University of Political Science and Law", and it is also the phased achievement for the research project: "Comparative studies of human rights discourse system in the field of Sino-French Criminal Law-Viewed from a perspective of Semiotics" (the project number: 1000-10815374).

1 The author is Professor at China University of Political Science and Law, PhD in Human Rights Law, Visiting scholar to the University of Exeter (the U.K.), Reviewer of the Journal of Political Science and Public Affairs (the U.s.).

(C) SUN, $2016 \mid$ DOI 10.1163/23525207-12340011

This is an open access article distributed under the terms of the Creative Commons Attribution- 


\section{Keywords}

Global governance - Human rights in China - Human rights discourse - Confucianism Peng-chun Chang

With China's sustained and rapid economic development, its comprehensive national strength gradually increased and its international status increasingly improved. China, as a rising world power, is currently playing a more and more important role in the international arena. However, at present, our country has not had a very good grasp of the discourse authority and dominance of human rights in global governance. Human rights have even become the "short board" and a source of weakness in the international exchanges of our country, which is not consistent with our country's status as a world power. In global governance, especially in the field of international exchanges concerning human rights, whether a country can grasp the discourse authority and dominance of the international discourse on human rights has become the touchstone of the country's "soft power". Therefore, we must face the reality of our country and analyze the weaknesses of China's human rights discourse in international exchanges. On the one hand, it remains imperfect with regard to innovation and development in China's human rights discourse, and it has not formed part of China's own maturing human rights discourse system; on the other hand, our country lacks sufficient self-confidence to get involved in international exchanges on human rights. Therefore, how to build and develop a human rights discourse in the Chinese context has become a major practical problem faced in our academic circles, and the construction of the Chinese human rights discourse in global governance has become a major social responsibility and obligation of China's academia. Just as Professor Dong Yunhu, a well-known human rights expert and a former Deputy Director of the Information Office of the State Council of China, clearly pointed out at the Third Working Group Seminar of the National Human Rights Research Institutes: "Innovation and development of China's human rights theory system and the system of discourse is the premise for enhancing China's discourse authority and dominance in international human rights fields, as well as a major responsibility of contemporary Chinese academia." ${ }^{2}$

2 Dong, Yunhu, "Making efforts to create and develop the human rights discourse system of our country", http://www.scio.gov.cn/zxbd/nd/2011/Document/1043972/1043972.htm. Visited on 15 March 2015. 
To solve the problem in the "innovation and development of China's human rights theory system and the system of discourse" in the ultimate analysis is to make use of conducting systematic research in the field of human rights, through the "three-in-one" idea: associating the ancient and the modern, integrating Chinese and Western, and linking theory to practice. Through academic research, starting from the reality of our country, we shall not only respect the universal principle of human rights protection, but also closely combine the great practice of our country, sorting out the relationship between human rights and other factors and clarifying China's human rights principled positions in global governance. Only after a series of in-depth studies of the relevant issues can our country have a good command of the discourse authority and initiatives in international exchanges on human rights. With regard to the innovation and development of China's human rights discourse, Professor Dong Yunhu put forward three further requirements:

First of all, we must gain a foothold in the practice of the contemporary Chinese modernization. The successful practice of the Chinese socialist modernization has established a paradigm for the non-capitalist development in world human history. Just as the development mode of capitalism is the material basis of western bourgeois human rights ideology and discourse system, the flourishing development model of socialism with the Chinese characteristics is the inexhaustible sources for the innovation and development of China's human rights thought and discourse system.... Secondly, we must learn carefully from the human rights elements in the excellent Chinese traditional culture.... Chinese traditional culture contains abundant humanitarian and human rights elements of respecting people, cherishing people, caring for people, developing people. We shall associate with the practice of the contemporary China and the world, conducting in-depth studies of the Chinese traditional culture from the perspective of human rights, discarding the gross composition, excavating and interpreting the human rights thought essence with the universal significance consistent with the spirit of the times, which will be an important source of innovation and development of the theory of human rights system and discourse system. Thirdly, we must fully learn from all the advanced human rights thoughts and experience of other countries and the international community.... Only the absorption and transformation of all valuable human rights achievements in theory and practice created in human history and on this basis of Chinese creative transformation and development according to the actual situation can our human rights theory and the discourse be truly representative 
of the development of the times spirit and the world progressive trends, understood and recognized by the people around the world. ${ }^{3}$

Obviously, it is a systematic project to establish China's human rights discourse, which requires joint efforts and the united strength of our academia. In this article, I would like to put forth several suggestions, the first of which concerns the establishment of China's human rights discourse. Thereafter, I will discuss four aspects of the core content of China's human rights discourse, including: the concept of human rights in traditional Chinese culture, the historical contribution of China to the construction of the international human rights system, practical achievements of China's human rights cause and the social construction of the Chinese human rights discourse, with the intention of prompting further discussion on this issue.

Fundamental Features of Constructing China's Human Rights Discourse

The construction of China's human rights discourse in recent years has become a hot topic for our government and academics, and it is inseparable from the rising status of China as a great power in the international arena. As an important and influential power, China, since its reforms and opening-up, has made remarkable achievements, and its comprehensive national strength has been greatly improved. In this situation, how to promote China's human rights discourse in global governance as a "soft power" of our country has become the focus of attention. In particular, in international exchanges, the human rights discourse has been controlled by certain Western powers for a long time, which has been used as tools and means against other countries. They manipulate the world media with an attempt to occupy the high ground of morality, damaging the international images of other countries so as to achieve a goal of world hegemony. As Professor Dong Yunhu pointed out:

With the rapid growth of China's hard power, the soft power building is obviously a short board. For a long time, the Western countries have dominated the pattern of the international dissemination, monopolizing the international discourse right, and China has been in an obvious

3 Dong, Yunhu, "Making efforts to create and develop the human rights discourse system of our country", http://www.scio.gov.cn/zxbd/nd/2011/Document/1043972/1043972.htm. Visited on 15 March, 2015. 
weak position in the pattern of communication and discourse system. This situation to a large extent has resulted in that China's voice could not go out and could not go far and the Chinese image has been distorted and defaced. In consequence, China has to face the embarrassing situations, having no place to say the reasons and having no people willing to listen to China's voice in the international community. ${ }^{4}$

Therefore, in order to completely break the passivity of international public opinion and to regain the right to speak, China must establish a set of rules for its human rights discourse. However, it is a complicated and systematic project to construct a set of rules for a maturing discourse system, and it can be said that "Rome was not built in a day", but "every journey begins with the first step". The very intelligent Chinese must be able to successfully establish a system to set up a human rights discourse and find the right place for our country in global governance.

First of all, by its very nature, the construction of a Chinese human rights discourse requires an interdisciplinary knowledge, associated with multiple disciplines covering historical, philosophical, legal, political, economic, social, cultural, linguistic, logic and other fields. Construction of a discourse on human rights is a process of historical review, which cannot be divorced from social reality. One should take a bird's eye view of ancient and modern ideas to study and discuss the relevant issues, standing at the height of philosophy to construct a human rights discourse and conducting extensive research on a series of problems. However, human rights discourse is an important legal problem after all, and its research cannot be completed without a discussion of the legislative, judicial and practical issues involving human rights. A human rights discourse per se is a composite superposition of human rights and discourse, and human rights are concerned with civil rights, political rights, economic, social and cultural (ESC) rights, the right to the environment and development. Therefore, research must be conducted from multiple perspectives including political, economic, social, cultural and ecological aspects, and "many chapters" of any human rights discourse may even be studied from a discourse analysis perspective. However, any interdisciplinary study may not go beyond the regulation of logic because, without logic, theories or words will become "a dish of sand", and it will be difficult to provide reasons and arguments. From this view, it is evident that it is an arduous task to construct

4 Dong, Yunhu, "Making efforts to create and develop the human rights discourse system of our country", http://www.scio.gov.cn/zxbd/nd/2011/Document/1043972/1043972.htm. Visited on 15 March, 2015 . 
China's discourse on human rights, which requires interdisciplinary thinking and comprehensive research.

Secondly, viewed in terms of content, the construction of China's human rights discourse includes the study of a composite of multiple relations. This study involves a series of relations, such as human rights and democracy, human rights and ethics, human rights and the rule of law, human rights and sovereignty, human rights and global governance, human rights and politics, human rights and economics, human rights and society, human rights and culture, human rights and ecology, human rights and individuals, human rights and the state ruled by law, and many other complicated relations. It also elaborates on the content regarding universality and particularity, the right to subsistence and the right to development, the subjects and objects of human rights, human rights content and types, rights and obligations, state sovereignty and non-interference in other states' internal affairs, dialogues and cooperation in the field of human rights, human rights education and human rights research, peace, development and human rights and other complex relations. In the process of constructing our country's human rights discourse, it is necessary to clarify and define all concepts accurately, and it is also necessary to clarify the relations between the different concepts. Moreover, every relation involves contents with very rich connotations worthy of being further explored, which also increases the complexity of the construction of China's human rights discourse.

Thirdly, viewed in terms of research methods, construction of China's human rights discourse involves comprehensive study, combining theory and practice. This study needs not only elaboration and analysis from a theoretical perspective, it also needs research associated with practical social problems. Therefore, this study has the characteristics of both qualitative and quantitative research methods, and, therefore, it is also not lacking in empirical research. For some problems in the protection of human rights, we need not only conduct an in-depth analysis from the point of view of jurisprudence, but we need also to provide a large amount of data to be explained in detail. For example, when discussing the Chinese representative, Peng-chun Chang's dominance in the process of drafting the Universal Declaration of Human Rights (UDHR), this represents a qualitative description. This kind of qualitative description indicates the author's opinions and ideas, but the language used is evaluative, which is clearly beneficial. However, the shortcoming lies in the possible existence of subjectivity. If empirical data can be provided to support it, the effect of persuasion will be greatly improved. We can see the following supportive data: "At its 187th meeting, there were a total of 33 country representatives participating in the discussion of the meeting with a total of 
55 speeches, and the representative of each country had less than two opportunities to speak on average. But Peng-chun Chang spoke for 5 times, accounted for $1 / 11$ of the entire speaking opportunities, which was 3 times than the average with $1 / 33$ of the total opportunities." In addition, all representatives talked about what the Chinese representative, Peng-chun Chang had said. This quantitative description strongly proves that the Chinese representative, Peng-chun Chang played a dominate role in the discussion.

Fourthly, viewed from the results of the study, the construction of China's human rights discourse is a dynamic and endless study. As mentioned by President Xi Jinping while commenting on human rights issues, "there are only better human rights rather than [the] best one". 6 This is a wonderful docking between China's discourse and the world's discourse (called "Good better best, never let it rest. Till good is better, But better best."), showing the excellent political wisdom and extraordinary diplomatic skills of our state leader. He is good at using words which can be understood by the Western world, and this is conducive to promoting and enhancing mutual understanding between different countries, which helps to win the trust of all peoples and the support of all countries in the world. It is only with a more tolerant attitude towards other countries' human rights issues, and with a more rigorous attitude towards and reflecting their human rights issues, being strict with oneself and lenient towards others in international exchanges on human rights that we will help to reduce or avoid that certain countries attack and destroy other countries' international reputations and images by using human rights issues.

In addition, the construction of China's human rights discourse is a dynamic process of development, in which a series of problems needs to be solved, such as how to evaluate the functions of traditional Chinese culture, how to represent the outstanding contributions made by China to the world's human rights cause, how to be loyal to China's basic national conditions and how to be in line with the trends of the development of international human rights, how to put forward basic principles in the present, how to solve the most urgent practical problems at the moment, how to prepare for and respond to Western human rights challenges and human rights discourse hegemony and so on. Great efforts are needed in many aspects of constructing human rights discourse in China because the constructing process has just begun. There is a lot

5 Sun, Pinghua, The Study of the Universal Declaration of Human Rights, Beijing, Peking University Press, 2012, p. 106.

$6 \mathrm{Xi}$, Jinping, "There is only better but no best concerning human rights issues", cited from the following website: http://news.xinhuanet.com/politics/2012-02/15/c_11152858o.htm. Visited on 15 March 2015. 
of work to do, for example, a need to carry out thorough and concrete research and a need for the joint efforts of the whole nation, especially the wisdom and astuteness of our academics!

With this view in mind, the content of China's human rights discourse is very rich; in addition to the human rights concepts contained in traditional Chinese culture, it also involves China's significant contribution to the process of constructing the international human rights system and the great practice of the Chinese human rights cause, including, mainly, the significant progress in China achieved with our country's first white paper ${ }^{7}$ released in 1991—Human Rights in China, "the state respects and guarantees human rights" included in the Constitution (2014), ${ }^{8}$ the release of the National Human Rights Action Plan of China (2009-2010), ${ }^{9}$ the formation of a socialist legal system with Chinese characteristics in 2010, ${ }^{10}$ and judicial protection of human rights in China, etc. In addition, combining the international human rights standards with China's basic national conditions and putting forward the fundamental principles for achieving international human rights standards in China ${ }^{11}$ shall set the tone for China's basic propositions made in international exchanges, which have become an important part of China's human rights discourse.

China's human rights discourse in terms of global governance includes an extremely broad and rich content, a dynamic and socio-constructive system, and extremely important values and far-reaching significance. We can discuss its core content from the concept of human rights in traditional Chinese culture as a starting point, and then carry out systematic research into the contributions made thereafter by the Chinese representative in the process of constructing an international human rights regime, and by integrating the practice with the great achievements of human rights protection in our

See Sun, Pinghua, The Study of the Universal Declaration of Human Rights, Beijing, Peking University Press, 2012, p. 284.

8 Ibid., p. 307.

9 Sun, Pinghua, On the National Human Rights Action Plan which represents a landmark, 3 Human Rights (2012), pp. 29-35. Or refer to 9 Politics of China (2012), pp. 3-9.

10 Sun, Pinghua, Human Rights Protection System in China, Springer, 2014, p. 141.

11 Sun, Pinghua, "Fundamental principles for achieving international human-rights standards in China", in L. S. Rossi and G. D. Federica (eds.), Fundamental Rights in Europe and China: Regional identities and universalism, Editoriale Scientifica, pp. 21-40. 
socialist country. In that way we can systematically construct China's dynamic system of human rights discourse in terms of global governance.

\subsection{The Concept of Human Rights in Traditional Chinese Culture ${ }^{12}$}

Though the term, human rights, was not clearly put forth in traditional Chinese culture, Confucian philosophy, as a typical representative of traditional Chinese culture, contains sufficient ideas of human rights (though Mohism did not become the orthodox idea of traditional Chinese culture, its thought of "giving universal love for the benefit of the people" contained lots of factors relevant to human rights, ${ }^{13}$ worthy of being explored). In traditional Chinese culture, Confucian thought laid an emphasis on the core values of "benevolence" (Rén), showing respect for people's dignity, pursuing the goal of realizing a society in harmony, attaching an importance to morality and depicting the Datong in the ideal world.

Confucian philosophy not only laid an emphasis on understanding others, tolerance of and compromise with each other, and on showing sympathy to others, it also claimed the conscience of human beings, social harmony, moral educational functions, social order and creativity. Human rights originate from human dignity, while human dignity comes from human beings' reasoning and conscience, which distinguishes human beings from animals. Rén (仁, rén) is the core concept of Confucian philosophy, which was coined by Kong Zi (孔子, Kǒngzǐ, K'ung Tse, 551-479 BC), an ancient Chinese philosopher whose ideas encouraged justice and peace by teaching social and moral principles which had a great influence on Chinese society, and whose Analects contain a collection of his sayings and dialogues compiled by disciples after his death. Rén was translated by Peng-chun Chang (Peng-Chun Chang) ${ }^{14}$ into "two-man-mindedness", which was well known in the Western world as "conscience" (良心, liángxīn). It was through the efforts of Chang ${ }^{15}$ that the concept of Rén was successfully included in the Universal Declaration of Human Rights formulated as a common standard for all peoples:

\footnotetext{
12 See Sun, Pinghua, Human Rights Protection System in China, Springer, 2014, pp. 4-7.

13 Li, Ming, Echo of Chinese Traditional Legal Ideology, Law Press, 2012, p. 62.

14 Chang was a Chinese representative to the United Nations Economic and Social Council (1946-1948). He participated in the drafting process of the Universal Declaration of Human Rights as a vice-chairman of the Commission on Human Rights, taking advantage of Confucian philosophy in the drafting process and making great contributions in mediation and solving disputes.

15 Sun, Pinghua, "Pengchun Chang, a globally famed Chinese human rights activist", 6 Human Rights (2011), pp. 29-30.
} 
It would regard the core concept of Confucianism as the essential attribute of human beings, and this core concept would become the philosophical foundation of human rights and fundamental freedoms in the Declaration. It was extremely significant just because it made the Declaration cover the non-Western concept of human rights, and it enhanced the universality of the Declaration, having universal value.... It has attracted attention of the Western world to the Chinese Confucianism and traditional culture. In this case, Chinese traditional culture got further recognized and respected by the Western world. ${ }^{16}$

In fact, the term of conscience was first coined by Meng Zi (孟子, Mèngzǐ, Meng Tse, 372-289 в ), a Chinese Confucian philosopher who taught that people are innately good and that one's nature can be enhanced or perverted by one's environment, and whose Works of Mencius is also very influential in the world. Meng Zi was the first great thinker to extend the teachings of Confucius. His teachings tended to increase the self-respect and self-confidence of man. He taught that the nature of man was good, and that the difference between man and animals, though very small, should be stressed and could be cultivated. One of the implications of this teaching of the essential goodness of the nature of man is the fundamental respect for what is "human" in all men. He emphasized the rights of the people as well as the obligation of the ruler to provide for the good of the people. When talking about the relationship between individuals, the state and the government, Meng Zi thought that the people were the most important element; the institutions were the next; and the sovereign the least important. (Mín wèi guì, shèjì cìzhī, jūn wèi qīng. 民为贵, 社稷次之, 君为轻。)

Confucian thought laid an emphasis on people's dignity, and human rights originate from human dignity. The Master said, "The commander of the army may be carried off, but the will of the common man can not be made to change." (Sān-jǔn kěyı̆ duóshuàiyĕ, pŭfū bùkĕ duózhìyĕ. 三军可以夺帅也, 匹夫不可夺 志也 ○ ${ }^{17}$ This shows that Confucius valued an individual's willingness regardless of his status. The Master said, "Do not do to others what you wouldn't like

16 Sun, Pinghua, The Study of the Universal Declaration of Human Rights, Beijing, Peking University Press, 2012, p. 98 and Sun, Pinghua, Historic Achievement of a Common Standard: Peng-chun Chang and the Universal Declaration of Human Rights, Springer (forthcoming).

17 Li, Tianchen (trans.), The Analects of Confucius, Jinan, Shandong University Press, 1991. (Note: Except for the Age of Grand Harmony, the Confucian doctrines quoted in the following paragraphs are all from this book.) 
yourself." (Jǔ suǒ bù yù, wù shī yǔ rén. 已所不欲, 勿施于人 ○) This has become a golden rule for human beings of the modern and civilized world.

More than 2,500 years ago, Confucius formulated the thoughts about The Age of Grand Harmony which express even today the dream of all mankind, while the thoughts contained in The Age of Grand Harmony compose a great blueprint described for human rights protection in traditional Chinese culture as follows:

When the Dadao or Grand Way prevails, the world is for the welfare of all. Officers are selected because of their virtue and competence. Mutual confidence is promoted and peaceful relations are maintained. People regard not only their own parents as parents, nor only their own children as children. Previsions are made for the aged, employment is provided for the able-bodied, and education is afforded to the young. Widows and widowers, orphans and the childless, the deformed and diseased, are all cared for. Men have their occupations and women have their homes. Surplus goods are not to be wasted; they need not be kept as one's own. Labor is not to be idle; work is not necessarily for self only. Scheming and intrigues are repressed and banditry and rebellion do not arise. As a result, there is no need of shutting the house-gate at night. Such is the Age of Grand Harmony. ${ }^{18}$

The quotation is a vivid picture, showing us an ideal society, in which people will achieve the highest and ultimate goal in realizing economic and social rights. This was the first Chapter of Human Rights in the history of humanity. It was formulated about 17 centuries earlier than the Magna Carta of 1215 .

Confucian philosophy cherishes morality rather than interests. The Master said, "A man of morality will never live in solitude; he will always bring companions." (Dé bù gū, bì yǒu lín. 德不孤, 必有邻 。) The Master also said, “A gentleman is conscious only of justice, a petty man, only of self-interest." (Jūnž̌ yùyúyì, xiǎorén yùyúlì. 君子喻于义, 小人喻于利 。) According to Confucius, "He who engages solely in self-interested actions will arouse continual discontent." (Fàng yú lì ér xíng, duōyuàn. 放于利而行, 多怨。) The Master also

18 Cited from Peng-chun Chang, "World significance of economically 'low pressure' areas," Speech at the Second Session of the Economic and Social Council, 4June 1946, reprinted in Ruth, H. C. and Sze-Chuh Cheng (eds.), Peng-chun Chang 1892-1957: Biography and Collected Works, Privately printed, 1995, pp. 151-153 and Glendon, M. A., A World Made New: Eleanor Roosevelt and the Universal Declaration of Human Rights, New York, Random House, 2001, p. 185 . 
said, "Wealth and rank unrighteously obtained seem to me as insubstantial as floating clouds." (Bùyì érfù qiěguì, yú wǒ rú fúyún. 不义而富且贵, 于我如浮 云 。) From the quotations above, we can safely draw a sound conclusion: in the Chinese tradition, people would rather give up wealth and interests than put themselves into an unrighteous position, which serves as a fundamental moral rule. Therefore, the Chinese cultural tradition leads to this kind of phenomenon. People put great stress upon duties and obligations and look down upon interests and rights. At the same time, traditional Chinese culture would lay emphasis on people's responsibilities and duties to others, to society and to the country rather than claiming rights in their social life. Much more attention has been given to moral standards concerning the relationship between rights and duties. People would not only pursue private rights, but also assume their obligations. While one respects and protects one's own rights, one must set a position for his or her duties and obligations to others. That is to say, people can enjoy their natural rights, but at the same time they have to carry out their duties and responsibilities in social relations. Only in this way can people avoid being overly selfish, and make the whole society a civilized one.

Human rights is a great term. However, only seeking to enjoy rights without taking responsibilities seems too selfish. If everyone just seeks one's own interest and rights without taking care of others' equal interests and rights, the whole world would come to an end. A human rights career is an endless business, but over pursuing one's own rights will lead to the opposite result, where one's feelings of greed would be further expanded. By contrast, the resources are limited, while pursuing personal human rights, people will take advantage of limited resources, which may belong to future generations. Once the resources are used up, human beings will find it difficult to survive. In this case, in order to save the whole world and to save human beings, we must learn from Confucian philosophy.

According to Confucius, it is the highest goal to pursue social harmony. The Master said, "In carrying out the rites it is harmony that is prized." (Lǐ zhī yòng, hé wèi guì. 礼之用, 和为贵 ॰) Here, harmony refers to a relationship between the body and heart of human beings, between human and human, between human and society, between human and nature (or the natural world). This brilliant idea should become a common moral standard for the whole world, which will bring people peace, happiness and harmony. Lasting world peace cannot be divorced from this moral standard. China is a peace-loving country, where morality is prized and social harmony is advocated. In some sense, the concept of harmony is a wonderful contribution to the theory of international human rights protection. The contemporary world should regard this principle as a common moral standard. 


\subsection{Historical Chinese Contributions to Establishing the International Human Rights Regime}

After humanity experienced two disastrous world wars, human rights have become the core issue of common concern for the international community. The Charter of the United Nations mentions "human rights" seven times, and the international human rights protection system has been constructed in the continuing practice of the United Nations, for which the drafting and adoption of the Universal Declaration of Human Rights laid a good foundation for the construction of an international human rights protection system. At the same time, the Declaration has also become an important milestone for the development of the international human rights agenda. China, as a founding member of the United Nations, has played an important role in the process of constructing the international human rights protection system. Especially in the drafting process of the Universal Declaration of Human Rights, the Chinese representative, Peng-chun Chang, included a series of human rights concepts in traditional Chinese culture into the entire drafting process, and successfully got the core concept of Confucianism "Rén" (Peng-chun Chang created a word "two-men-mindedness", which was translated by his colleagues into "conscience") written into the first article of the Declaration, which serves as a philosophical foundation for the whole declaration, and the concept of "conscience" became the ultimate source for legitimacy of human rights argued by the international community. This contributed to the Universal Declaration of Human Rights' universality and a common standard of achievement for all peoples and all nations. Moreover, because the core concepts of Confucianism were included in the first human rights instrument for all of humanity (the first instrument drafted for the International Bill of Human Rights), it became possible for the Western world to know and further understand traditional Chinese culture and human rights concepts through the Declaration. In this sense, Peng-chun Chang's outstanding contributions became the crucial content and core chapter that the Chinese people made in the constructing process of the international human rights system, laying a foundation for the constructing of a Chinese system of discourse on human rights in terms of global governance.

\subsubsection{The Chinese Representative, Peng-chun Chang}

In the process of constructing the international human rights system, there was an outstanding Chinese representative-Peng-chun Chang-whose contributions have been recorded forever in the history of the development of international human rights. He participated in the drafting of the Universal Declaration of Human Rights and made a very significant contribution. The 
Declaration became the first human rights document for all of humanity, and it became a cornerstone in the construction of an international system of human rights protection, thus opening a new era of global human rights protection. The official website of the United Nations introduces Mr. Peng-chun Chang as follows: "Playwright, philosopher, educator and diplomat, Mr. Pengchun Chang, was well known in his country as a director of Chinese modern drama. He was able to explain the Chinese concept of human rights to the other delegates and creatively resolved many stalemates in the negotiation process by employing aspects of Confucian doctrine to reach compromises between conflicting ideological factions. He insisted, in the name of universalism, on the removal of all allusions to nature and God from the Universal Declaration of Human Rights."19

\subsubsection{Peng-chun Chang's Contributions to the Universal Declaration of Human Rights}

China has made great contributions to the establishment of the international human rights protection system and these great contributions have been made through Chinese philosophical thought, China's traditional culture and the intelligence and wisdom of the Chinese people. For instance, these contributions were made by the Chinese representative, Peng-chun Chang, while serving as a vice chairman of the United Nations Commission on Human Rights. Regarding Peng-chun Chang's contributions, I have discussed in my book entitled The Study of the Universal Declaration of Human Rights, published in 2012, an in-depth exploration from the following eight perspectives: ${ }^{20} 1$ ) putting forth the overall drafting plan and defining the Declaration accurately; 2) adherence to traditional Chinese culture and successful integration of Confucianism; 3) insisting on the universality of human rights and solving the disputes about the origins of human rights; 4) using extraordinary wisdom and creatively breaking deadlocks and resolving conflicts; 5 ) dominating the right to speak in the drafting process with profound knowledge; 6) thinking from a philosophical perspective and expounding on Chinese views on human rights to the world; 7) advocating the principle to be brief and readily understandable with rigorous structure; and 8) emphasizing economic, social and cultural rights and proposing the concepts of mutual tolerance and harmonious society.

\footnotetext{
19 Peng-chun Chang, http://www.un.org/Depts/dhl/udhr/members_pchang.shtml (visited on 15 March 2015).

20 Sun, Pinghua, The Study of the Universal Declaration of Human Rights, Beijing, Peking University Press, 2012, pp. 93-112.
} 
Here I would like to quote the words from Peng-chun Chang's colleagues, including Mrs. Eleanor Roosevelt (Chairman of the United Nations Commission on Human Rights), Charles Malik (Rapporteur of the United Nations Commission on Human Rights), John Humphrey (First Director of the United Nations Human Rights Division) and an evaluation from the Department of State of the United States to demonstrate Peng-chun Chang's contributions to the construction of the international human rights system: ${ }^{21}$

Mrs. Roosevelt mentioned Peng-chun Chang three times in her memoirs, On My Own. First, she mentioned the general impression he made on her throughout the process of drafting the UDHR. Second, she mentioned Pengchun Chang's philosophical opinion, and, third, she mentioned Peng-chun Chang's individual charming manner in the drafting process. To take just one example: Mrs. Roosevelt wrote: "Dr. P. C. Chang, who was a great joy to all of us because of his sense of humour, his philosophical observations and his ability to quote some apt Chinese proverb to fit almost any occasion."22

Charles Malik highly sang the praise of Peng-chun Chang's contributions; he stated: "It is impossible even to begin to name the hundreds of individuals and institutions that had something to do, directly or indirectly, with our work in its initial stages. However, I must refer to Dr. P. C. Chang, the distinguished vice-chairman of the Commission and drafting committee. He never failed to broaden our perspective by his frequent references to the wisdom and philosophy of the Orient and, by a special drafting gift, was able happily to rectify many of our terms."23

John Humphrey said: "He was a master of the art of compromise and, under cover of a quotation from Confucius, would often provide the formula which made it possible for the Commission to escape from some impasse." ${ }^{24}$ "In Intellectual stature, he (Chang) towers over any other member of the

21 Sun, Pinghua, Historic Achievement of a Common Standard: Pengchun Chang and the Universal Declaration of Human Rights, Springer (forthcoming).

22 Roosevelt, Eleanor, On My Own, Harper, 1958, p. 77 and Roosevelt, Eleanor, On My Own, Hutchinson \& Co. (Publisher) Ltd., 1958, p. 95.

23 Malik, Charles, 9 December 1948, speech to the General Assembly, in H. C. Malik (ed.), The Challenge of Human Rights: Charles Malik and the Universal Declaration, Oxford, Centre for Lebanese Studies, 2000, pp. 120-121.

24 Humphrey, J. P., "The Memoirs of John P. Humphrey, the First Director of the United Nations Division of Human Rights", Human Rights Quarterly 5/4 (1983), 387-439 (pp. 396-397). See also Humphrey, J. P., Human Rights and the United Nations: A great adventure, New York, Transnational Publishers, 1984, p. 23. 
committee." ${ }^{25}$ Here, Humphrey was referring to the Third Committee of the General Assembly of the United Nations. Chang resigned from the UN in $195^{2}$ because of his worsening heart condition, and he died in 1957. John Humphrey, on hearing the news, wrote in his diary: "P. C. Chang is dead. Of all the delegates who came into the Council, he was the one with whom I felt most in spiritual and intellectual communion. And the one I like the best.... He was a scholar and, in a way, an artist although he performed his diplomatic functions well in spite of these superior gifts. What a giant he seems in contrast with the time-servers." 26

The State Department of the United States also showed high appreciation for Peng-chun Chang's contributions by adding: "Chang died in 1957. He did not live to see the adoption of the subsequent International Covenants on Human Rights, which made the UDHR binding and were part of his solution for enforcing human rights around the world."27 The supposition of this evaluation made by the U.s. Department of State is that the whole solution for enforcing human rights around the world was put forward by Peng-chun Chang, including the Universal Declaration of Human Rights and the core international human rights conventions. Based on this evaluation and viewed from an historical perspective and the practical contributions, Peng-chun Chang deserved to be called a principal architect of the international human rights system.

Although Peng-chun Chang had few academic achievements before he participated in the drafting, as a philosopher, educator, diplomat and master of the art of language, his experience, the Japanese invasion, especially the keenly-felt pain of the bombed out of Nankai University and his activities of human rights in the national diplomacy deepened his understanding of human dignity and the principles of human rights. His contribution to the drafting of the Universal Declaration of Human Rights was not fortuitous. It was due to his wisdom, scholarly reflection, and broad vision, eastern and western way of thinking and extraordinary competence of using English language. Besides, his contribution also owed to the nourishing and cultivation of Chinese tradition culture. His style of citing Confucian classic sayings not only showed his profound understanding of Chinese tradition culture, but also reflected the great influence of Chinese tradition culture on him. During the drafting process, sometimes he proposed advice and solutions which was accepted, sometimes

25 Hobbins, A. J. (ed.), On the Edge of Greatness: The Diaries of John Humphrey, First Director of the United Nations Division of Human Rights, Volume 1, 1948-1949, Montreal, McGill University Libraries, 1994, p. 88.

26 Hobbins, On the Edge of Greatness, op. cit., pp. 232-233.

27 eJournal USA 13/11 at http://www.america.gov/publications/ejournals.html. 
he posed a question for further discussion and clarification, and during the dispute resolving process, sometimes he gave significant advice, sometimes he declared his own philosophy. His attitude and outstanding competence during the drafting process made great contribution to the organization of the drafting. For what he did for the global human rights cause, he was regarded by many as a 'giant' - a cultural giant, a giant in the realm of human rights and a giant of the era. In some degree, his contribution is the significant contribution made by Chinese civilization, national wisdom and excellent culture heritage. ${ }^{28}$

\subsubsection{The Status of the UDHR in Constructing the International Human Rights System}

The Universal Declaration of Human Rights has played an extremely important role in the field of international human rights, international law, UN affairs, international politics as well as national human rights protection. Professor Zhao Jianwen once wrote in an article that the Universal Declaration of Human Rights was: "the cornerstone of the international human rights law". ${ }^{29}$ It set up a common standard of achievement for all peoples and all nations. Since the adoption of the Universal Declaration of Human Rights, more than 6o years of practice in constructing the international human rights system has proved its significance, which has gone far beyond the imagination of the drafters, because it has already influenced many fields such as philosophy, law, culture, international politics, human society, diplomacy, human development, nature, education, people, the daily life of people and so on. It has become the cornerstone and a milepost for constructing the international human rights system.

As just indicated, the drafting and adoption of the Universal Declaration of Human Rights served as a milestone for the construction of the international human rights system, and its signature was of extreme historical significance and far-reaching international influence, opening up a new era of history in the protection of human rights. This is because the Universal Declaration of Human Rights

not only provides authoritative interpretations on human rights clauses for the UN Charter, but is also considered to be an important part of the customary international law; besides, it involves more than just setting up a common standard of achievement for all nations and all peoples

28 Sun, Pinghua, "Zhang Pengchun, a globally famed Chinese human rights activist", 6 Human Rights (2011), pp. 40-45.

29 Zhao, Jianwen, "The cornerstone of the international human rights law", 2 Chinese Journal of Law (1999), pp. 93-107. 
to strike for, it is also an important basis for international human rights legislation. Furthermore, the UDHR has explicitly provided a moral regulation of behaviors for Member States and individuals in UN. As the fundamental principles of the Declaration are adopted by international human rights advocates, many international conventions are made largely based on the UDHR, and the Regional Conventions on Human Rights and Constitutions in many countries are made directly referred to the UDHR. ${ }^{30}$

\subsection{The Rejuvenation and Progress of the Human Rights Cause in China}

The Chinese human rights cause is an important part of humanity's human rights cause, and the rejuvenation of the Chinese human rights cause and its achievements are worthy of further research. In the review of the progress in the Chinese human rights cause, I have pointed out:

Though there have been painful lessons of the 'Cultural Revolution' since the founding of a new China, outstanding achievements have been made by China in human rights protection, and especially since the reform and opening up more than thirty years ago, with the rapid development of the national economy, the people's living standard has been increased, citizens have been enjoying the increasingly rich rights, China's overall level of human rights protection has continuously been raised and human rights conditions have continuously been improved. ${ }^{31}$

Since 1 November 1991, when the Chinese government issued its first white paper on human rights-Human Rights in China-, the Chinese human rights cause has made great progress in many aspects. In 2004, the statement, "the state respects and guarantees human rights" was enshrined in the Constitution, which was known by everyone as the entry of "human rights into the Constitution". It clearly provided for the constitutional principle that "the state respects and guarantees human rights", symbolizing that our country entered into a new era of human rights protection according to law, and it became a new milepost in the development of the human rights cause in China. On 13 April 2009, the Information Office of the State Council issued the National Human Rights Action Plan (2009-2010), which "is the first human-rights-themed national plan formulated by the Chinese government,

\footnotetext{
30 Sun, Pinghua, The Study of the Universal Declaration of Human Rights, Beijing, Peking University Press, 2012, pp. 191-192.

31 Ibid., p. 286.
} 
and is the policy paper of the action program to put into practice the constitutional principle 'the state respects and guarantees human rights' and advances China's human rights cause". ${ }^{2}$ This action plan provides not only the protection of economic, social and cultural rights, and civil and political rights, but also measures to protect the rights of ethnic minorities, women, children, the elderly and the disabled. On 11 June 2012, our country issued the National Human Rights Action Plan (2012-2015), further promoting the constructive development of human rights protection in China. On 23 October 2014, the Fourth Plenary Session of the 18th CPC Central Committee adopted the Decision on Major Issues Concerning Comprehensively Promoting the Rule of Law, which not only indicates the Communist Party's firm determination to comprehensively promote the rule of law, but also marks the entry of a new era where human rights are guaranteed in accordance with the law, which will greatly promote the development and progress of the human rights cause in China.

Wang Chen, Director of the Information Office of the State Council, once pointed out that the major Chinese achievements of the human rights cause could be seen in the following five aspects:

First, unprecedented attention has been given to respecting and safeguarding human rights, which has become an important principle for the CPC and Chinese government in managing state affairs. Second, the people's rights to subsistence and development have been ensured in an unprecedented way. Third, the people's civil rights and political rights have been practically guaranteed. Fourth, the people's economic, social and cultural rights have been continuously improved. Fifth, international communication and cooperation have been constantly expanded. ${ }^{33}$

Of course, China is a large developing country with a huge population, a relative scarcity of resources and tremendous pressure in the field of environmental protection. Coupled with the impact of the traditional Chinese legal system and many other factors, there must be, in reality, a lot of aspects of China's situation which are not satisfactory. Therefore, we must adopt a positive attitude, daring to face the problems and not evade reality and seek effective methods and ways to solve the existing problems through the joint efforts of the entire

32 Wang, Chen, "Major measures to advance the all-round development of human rights in China", China Daily. April 15th, 2009, p. 8.

33 Wang, Chen, "China's human rights have made a historic progress", 6 Human Rights (2008), pp. $2-7$. 
Chinese nation. Any other power cannot really help a country to solve its practical problems; thus, to further develop the cause of safeguarding human rights, our country must rely on our own efforts. Therefore, we need to strengthen research into realistic problems, exploring the strategies and methods to solve these problems. Only when we do our assignments well in this respect can we self-confidently and bravely face the challenges of the Western powers' blame and criticism; and we will take China's human rights discourse as the basis for occupying the commanding point of international human rights discourse in international exchanges, achieving "rational, beneficial, and procedural" effectiveness and commanding initiative and leadership in the international human rights discourse.

\subsection{Social and Dynamic Construction of China's Human Rights Discourse}

It is time to develop the entire theory of human rights and human rights discourse, and these ten principles ${ }^{34}$ have been put forth as follows: (1) integrating the universality of human rights with country-specific situations; (2) giving priority to the right to subsistence and the right to development; (3) recognizing human rights for all members of society; (4) realizing the goal of an "allaround" development of human rights; (5) balancing rights and obligations in promoting the development of human rights; (6) stressing human rights and social stability, economic development, and the relevant legal construction; (7) assessing human rights as an essentially domestic affair of a sovereign state; (8) promoting the international human rights cause through talks and cooperation; (9) emphasizing human rights education as a basic measure in promoting human rights; and (10) pointing out that peace, development, and human rights contribute to a harmonious world.

However, the construction of our country's human rights discourse is an arduous and complex task. The entire construction process is compatible with the dynamic development of our society, so it will be a dynamic development with important practical significance. At the same time, in terms of global governance, the construction of a Chinese human rights discourse should consider international human rights standards and the mainstream human rights discourse by using language that the Western world can understand to elaborate China's views and proposals for a human rights discourse. In the practice of the international community's communications, we should start

34 Sun, Pinghua, "Fundamental principles for achieving international human-rights standards in China", in L. S. Rossi and G. D. Federica (eds.), Fundamental Rights in Europe and China: Regional identities and universalism, Editoriale Scientifica, 2013, pp. 21-40. 
from the reality of our country, further elaborating on the classical meaning of traditional Chinese culture, mining rights elements from traditional concepts, seeking the important role played by China in the construction of the international human rights system from an historical viewpoint, and highlighting the contribution to the world of Chinese wisdom. While reviewing the history, we should display China's human rights progress and great achievements in the major changes in contemporary society in China. This would be in order to raise the theoretical research level of human rights in China by summarizing and improving China's human rights discourse, which will, in turn, play a very important role in its more and more frequent international exchanges. This will also be to enhance further China's cultural soft power, and to construct the human rights discourse adapted to our image as a world power, as well as to further grasp the initiative and the dominant power in future international human rights exchanges and dialogues.

\section{Conclusions}

Professor Dong Yunhu, the well-known Chinese human rights expert, once pointed out:

In some sense, any one, who has the right of discourse and the dominant power in the field of human rights, occupies the moral high ground and masters the international public opinion. The international human rights struggle is essentially the struggle for the right of discourse and the dominant power. At present, the international community is not only full of expectation of China's development, but also with doubts, and human rights issues are always the main means used by the Western world distorting and defacing China and misleading the international public opinions. Therefore, the innovation and development of Chinese human rights discourse and enhancement of China's human rights discourse right are not only the requirements of beating back of western human rights offensive and safeguarding national security, but also the inevitable requirements of enhancing the national image and national soft power, creating a favorable international public opinion environment for China's peaceful rise. ${ }^{35}$

35 Dong, Yunhu, "Making efforts to create and develop the human rights discourse system of our country", at http://www.scio.gov.cn/zxbd/nd/2011/Document/1043972/1043972.htm. Visited on 15 March 2015. 
As a great power with an oriental civilization and a rising international status, China does not accord with its status raised day by day in terms of global governance and the human rights discourse, and human rights have even become the handle used by Western countries to attack China. It is based on this understanding that the construction of a Chinese human rights discourse becomes an urgent problem to be solved. In order to investigate the content of China's human rights discourse, we must adopt approaches to understand thoroughly both the past and the present, both Chinese and Western thought, and integrate theory into practice by combining international standards with Chinese situations. As a result, the construction of a human rights discourse suitable to China's status as a superpower shall serve to have China master the human rights discourse and have a leading position in international communications. 